\title{
Good, better, engaged? The effect of company-initiated customer engagement behavior on shareholder value
}

\author{
Sander F. M. Beckers ${ }^{1} \cdot$ Jenny van Doorn ${ }^{2} \cdot$ Peter C. Verhoef $^{2}$
}

Received: 20 October 2015 / Accepted: 19 April 2017 /Published online: 19 May 2017

(C) The Author(s) 2017. This article is an open access publication

\begin{abstract}
In today's connected world, customer engagement behaviors are very important. Many companies launch initiatives to stimulate customer engagement. However, despite evidence that customer engagement behavior also matters to shareholders, academic research on the firm value consequences of customer engagement campaigns is limited. This study is the first to investigate the value-related consequences of firm-initiated customer engagement behaviors, using shareholder evaluations of the public announcements of such initiatives. We find that companies' customer engagement initiatives, on average, decrease market value, which is likely because the shareholders are sensitive to the risk of these initiatives backfiring. Nevertheless, initiatives that stimulate word-of-mouth are viewed less negatively than initiatives that solicit customer feedback, as are initiatives that are supported by social media. Companies that operate in a competitive environment or do not advertise much can create value by stimulating customer engagement, while
\end{abstract}

Shrihari Sridhar served as Area Editor for this article.

Electronic supplementary material The online version of this article (doi:10.1007/s11747-017-0539-4) contains supplementary material, which is available to authorized users.

Sander F. M. Beckers

s.f.m.beckers@gmail.com

Jenny van Doorn

j.van.doorn@rug.nl

Peter C. Verhoef

p.c.verhoef@rug.nl

De Nieuwe Zaak, Zwolle, The Netherlands

2 Department of Marketing, Faculty of Economics and Business, University of Groningen, P.O. Box 800, NL-9700 AV, Groningen, The Netherlands companies with a strong corporate reputation are likely to not benefit from it.

Keywords Customer engagement $\cdot$ Shareholdervalue $\cdot$ Event study $\cdot$ Word-of-mouth

Academic and managerial interest in customer engagement is increasing, and it shows no signs of flagging. Customer engagement behaviors - i.e., non-transactional customer behavior such as commenting on a company's Facebook page, or recommending a service - imply that customers take an active role in value creation, participate in the company's value chain, and become co-producers of value (Vargo and Lusch 2004). Companies have therefore undertaken proactive efforts to initiate, steer, and manage customer engagement (Verhoef et al. 2010). We coin the term firm-initiated customer engagement for companies' explicit strategies to stimulate customer engagement; for example, by asking customers to "like" brands on Facebook or to create brand videos on YouTube.

Yet it remains unclear whether such efforts always benefit the firm. McDonald's, for instance, encountered the dark side of firm-initiated customer engagement when a Twitter campaign set up to promote positive word-of-mouth became a platform to bash the chain. An initiative of General Motors to let customers tweak its advertisements ended up with consumers highlighting the contribution of SUVs to global warming (Verhoef et al. 2013). The implications of firm-initiated customer engagement for a company's financial bottom line is therefore of great interest to managers and shareholders alike. Carrabis (2014) reports that less than $8 \%$ of managers are satisfied with the return on investment of their social marketing campaigns, and Porter et al. (2011) assert that half of the customer engagement initiatives offered through firm-sponsored online communities ultimately erode firm value. 
Academic research on the firm value consequences of firminitiated customer engagement campaigns is limited to date, however, with the existing literature instead focusing on conceptualizing customer engagement and its antecedents and consequences (e.g., Beckers et al. 2014; Brodie et al. 2011; Pansari and Kumar 2017; Verhoef et al. 2010). A noted exception is the study of Kumar and Pansari (2016), who find that customer engagement has a positive effect on company performance. Furthermore, there is some research suggesting that word-ofmouth and online chatter can increase firm performance and shareholder value (e.g., Babić Rosario et al. 2016; Gopinath et al. 2014; Liu 2006). Given the scarcity of research on the engagement-performance relationship, the first goal of this paper is to investigate the market value consequences of firm-initiated customer engagement behavior. Because of the uncertain outcomes of customer engagement initiatives, we expect substantial heterogeneity across initiatives because several opposing mechanisms amplify or decrease the effects of firm-initiated engagement. Our second goal is thus to investigate which factors affect the market value consequences of firm-initiated customer engagement behavior.

To address these key research questions, we use an event study (MacKinlay 1997) to evaluate the effectiveness of companies' customer engagement initiatives (i.e., word-of-mouth and customer voice initiatives occurring in various settings) according to shareholders' evaluations. We make two main contributions to the extant literature. First, we investigate the market value consequences of firm-initiated customer engagement behaviors. Most research on distinct customer engagement behaviors investigates their benefits (e.g., Fuchs et al. 2010; Gruen et al. 2006); we recognize that customer engagement behaviors can also have a dark side and assess their net effect. Second, we respond to Leeflang's (2011) call for research on "ways to determine the firms for which [the customer engagement] concept is most appropriate" (p. 78).

\section{Conceptual development and hypotheses}

\section{Customer engagement}

Customer engagement has attracted attention within the marketing discipline for a decade, specifically as a consequence of the rise of social media and an acknowledgement that customers can co-create and also destroy value (e.g., Libai et al. 2010; Verhoef et al. 2010). Van Doorn et al. (2010) define customer engagement behaviors as "the customer's behavioral manifestations toward a brand or firm, beyond purchase, resulting from motivational drivers" (p. 253). Examples are writing a review on TripAdvisor, commenting on a company's Facebook page, participating in a brand community, or recommending a product to a fellow customer.
Table 1 provides a non-exhaustive overview of literature on customer engagement and reveals that there has been some debate about the scope of customer engagement. First, researchers have broadened the scope of customer engagement behaviors to also include transactional behavior (i.e., buying) as well as behavior beyond transactions (i.e., referring, influencing) (e.g., Kumar et al. 2010a; Pansari and Kumar 2017). This results in "customer engagement value", which includes customer lifetime transaction-based value and non-transactional value (i.e., customer referral value) (Kumar et al. 2010a). Previous studies have also collapsed firm- and customer-initiated engagement in one customer engagement construct.

Considering this extended behavioral definition of customer engagement, Kumar and Pansari (2016) show that customer engagement increases a firm's performance. Yet, given sufficient evidence that strategies aiming to influence customer loyalty and customer lifetime value increase performance (e.g., Kumar and Shah 2009; Kumar and Reinartz 2016), it may very well be that these positive performance effects are due to increased transactional customer engagement behavior, rather than non-transactional customer engagement behavior. This extended conceptualization of customer engagement does not allow for disentangling the performance consequences of the measures stimulating transactions from those stimulating non-transactional customer behavior.

Second, Brodie et al. (2011) and related studies (e.g., Hollebeek 2011) have opted for a more attitudinal perspective on engagement, thereby acknowledging its behavioral outcomes. Summing up, Table 1 shows that researchers agree that customer engagement contains, but may not be restricted to, nontransactional behavior. Furthermore, in all conceptualizations customer engagement contains a behavioral component, where some authors additionally consider an attitudinal perspective. We therefore in our customer engagement definition focus on the elements where we find broad agreement on in the literature and define it as behaviors that go beyond customer transactions, such as, for example, word-of-mouth (e.g., Van Doorn et al. 2010). This means that we focus on customer engagement behavior, taking the perspective of the value-creating role of the customer. This more narrow definition of customer engagement allows us to focus on the value-related consequences of stimulating non-transactional behavior, which is clearly acknowledged as a very important aspect of customer engagement (see Alexander and Jaakkola 2016). We thus explicitly do not consider value creation through transactions, which is well covered in the customer relationship management literature (e.g., Kumar and Reinartz 2016; Verhoef and Lemon 2013). Furthermore, we restrict ourselves to concrete customer behaviors.

We further distinguish between customer-initiated and firminitiated customer engagement (e.g., Vivek et al. 2012). Customer-initiated engagement arises predominantly due to the internal motivational state of customers, irrespective of explicit intended company actions. Firm-initiated customer engagement 
Table 1 Summary of select customer engagement literature

\begin{tabular}{|c|c|c|c|c|c|c|}
\hline \multirow[t]{2}{*}{ Study } & \multirow[t]{2}{*}{ Study type } & \multicolumn{2}{|c|}{ Conceptualization of CE } & \multicolumn{2}{|c|}{ Scope of CE } & \multirow[t]{2}{*}{ Main finding } \\
\hline & & Attitude & Behavior & $\begin{array}{l}\text { Trans } \\
\text { actions }\end{array}$ & $\begin{array}{l}\text { Non-transactional } \\
\text { behavior }\end{array}$ & \\
\hline Brodie et al. (2011) & Conceptual & $\checkmark$ & $\checkmark$ & $\checkmark$ & $\checkmark$ & $\begin{array}{l}\mathrm{CE} \text { is a psychological state that occurs under } \\
\text { a specific context. }\end{array}$ \\
\hline Brodie et al. (2013) & Empirical & $\checkmark$ & $\checkmark$ & & $\checkmark$ & $\begin{array}{l}\text { CE leads to connection and emotional bonding, } \\
\text { customer empowerment, customer loyalty } \\
\text { and satisfaction, trust and commitment. }\end{array}$ \\
\hline Hollebeek (2011) & Conceptual & $\checkmark$ & $\checkmark$ & & $\checkmark$ & $\begin{array}{l}\mathrm{CE} \text { is a motivational, brand-related and context- } \\
\text { dependent state of mind characterized by } \\
\text { specific levels of cognitive, emotional and } \\
\text { behavioral activity. }\end{array}$ \\
\hline Hollebeek et al. (2014) & Empirical & $\checkmark$ & $\checkmark$ & & $\checkmark$ & $\begin{array}{l}\text { Consumer brand engagement positively impacts } \\
\text { self-brand connection and brand usage intent. }\end{array}$ \\
\hline Hollebeek et al. (2016) & Conceptual & $\checkmark$ & $\checkmark$ & $\checkmark$ & $\checkmark$ & $\begin{array}{l}\text { Develop an integrative framework of } \mathrm{CE} \text { and } \\
\text { the service dominant logic. }\end{array}$ \\
\hline $\begin{array}{l}\text { Jaakkola and } \\
\text { Alexander (2014) }\end{array}$ & Qualitative & & $\checkmark$ & & $\checkmark$ & $\begin{array}{l}\text { CE behavior affects value co-creation because } \\
\text { customers contribute resources toward the } \\
\text { focal firm and other stakeholders. }\end{array}$ \\
\hline Kumar and Pansari (2016) & Empirical & & $\checkmark$ & $\checkmark$ & $\checkmark$ & $\mathrm{CE}$ has a positive effect on company performance. \\
\hline Kumar et al. (2010a) & Conceptual & & $\checkmark$ & $\checkmark$ & $\checkmark$ & $\begin{array}{l}\text { Develop the CE value framework consisting } \\
\text { of four components. }\end{array}$ \\
\hline Pansari and Kumar (2017) & Conceptual & & $\checkmark$ & $\checkmark$ & $\checkmark$ & $\begin{array}{l}\text { Propose a conceptual framework including } \\
\text { antecedents (satisfaction and emotion) and } \\
\text { consequences of CE. Distinguish between direct } \\
\text { (transactions) and indirect (non-transactions } \\
\text { behavior) contributions of CE. }\end{array}$ \\
\hline Van Doorn et al. (2010) & Conceptual & & $\checkmark$ & & $\checkmark$ & $\begin{array}{l}\mathrm{CE} \text { is a behavioral manifestation towards a firm } \\
\text { beyond purchases. }\end{array}$ \\
\hline Vivek et al. (2012) & Qualitative & $\checkmark$ & $\checkmark$ & $\checkmark$ & $\checkmark$ & $\begin{array}{l}\text { CE contains cognitive, emotional, behavioral and } \\
\text { social elements. Distinguish between customer- } \\
\text { and firm-initiated CE. }\end{array}$ \\
\hline This study & Empirical & & $\checkmark$ & & $\checkmark$ & $\begin{array}{l}\text { Announcement of firm-initiated CE negatively } \\
\text { affects shareholder value. Type of CE, use of } \\
\text { social media, competitive intensity, advertising } \\
\text { intensity and corporate reputation function as } \\
\text { moderators. }\end{array}$ \\
\hline
\end{tabular}

occurs when firms adopt explicit strategies to stimulate customer engagement; for example, by asking customers to share a viral marketing campaign, to "like" the brand on Facebook, or to engage in a firm-sponsored online community. ${ }^{1}$ Unlike

\footnotetext{
${ }^{1}$ Specific actions, such as responding to a company tweet (e.g., a re-tweet, or a "like"), can be considered as firm-initiated customer engagement as long as the firm explicitly aims to stimulate this. While traditional advertising may also stimulate customers to engage and comment about the ad or the company (e.g., Srinivasan et al. 2015), the explicit goal of advertising is to create brand awareness and brand preference, rather than to stimulate customer engagement behavior. Even so, TV advertising can be a part of firm-initiated customer engagement, as long as the advertising explicitly stimulates this, for example by asking customers to promote the brand or to "like" the brand on Facebook. In the same vein, while we acknowledge that event marketing and customer relationship marketing activities can lead to customer engagement, we only classify the resulting engagement as firm-initiated if the company explicitly asked customers to become active on its behalf.
}

traditional marketing interventions, firm-initiated engagement initiatives do not intend to induce a sale but primarily seek to build strong, long-term relationships with customers. Differing from conventional forms of one-way communication, from the firm to the customer, firm-initiated engagement initiatives tend to be interactive and elicit participative experiences (Gill et al. 2017, p. 6).

In Table 1 we show how our study differs from the existing literature. By considering the shareholder value consequences of firm-initiated non-transactional customer engagement we clearly differ from existing empirical studies (e.g., Kumar and Pansari 2016). We emphasize not only the potential benefits but also the risks of customer engagement. 


\section{The impact of firm-initiated customer engagement on market value}

Literature on the link between a company's marketing and financial performance discusses different ways in which marketing measures can affect a company's financial performance, in particular (1) by affecting the efficiency and effectiveness of value creation (thereby enhancing and accelerating cash flow), (2) by building customer relationships (thereby growing the customer base, and consequently the residual value of cash flows), and (3) by increasing or decreasing risk (Srivastava et al. 1998).

Efficiency and effectiveness of value creation In principle, one would assume that customer engagement is positive for value creation (e.g., Pansari and Kumar 2017). When stimulating customer engagement behaviors, companies involve customers "in activities that were once reserved for the firm: promoting the brand, suggesting ideas for new products, choosing advertising copy, deciding on logos, and even reacting to competitive actions" (Libai 2011, p. 275). Customers take over functions from the companies' employees, and thereby companies can save on expenditure in such areas as advertising and product support (Villanueva et al. 2008). For instance, by stimulating word-of-mouth, companies involve customers in advertising and acquisition functions, to such an extent that customers act as a nonemployed sales force (Kumar et al al. 2010b; Villanueva et al. 2008). By soliciting customer feedback (e.g., voice), companies listen in on their (potential) customers pointing out issues in their product and service offerings (Hirschman 1970), which may prevent problems spreading to the whole customer base, and thereby save the cost of product recalls and/or service recovery.

Stimulating customer engagement behaviors can also be a more effective way to promote products, for example, as customer recommendations are likely to be more trustworthy (and therefore, more effective) than traditional one-way advertising efforts (Hoyer et al. 2010; Liu-Thompkins and Rogerson 2012; Trusov et al. 2009).

Building customer relationships Stimulating customer engagement behaviors can build and deepen customer relationships, as it creates additional customer-firm interaction points beyond the point of purchase (Jaakkola and Alexander 2014; Van Doorn et al. 2010). During these additional interactions, customers can actively form opinions about the focal company, learn about the firm's customer orientation and responsiveness (Borle et al. 2007), and/or become empowered and more attached to the company's offerings (Fuchs et al. 2010). The dialogue that customers are able to have with companies can also provide a favorable experience in itself (e.g., in gamification initiatives) and create relational value (Chan et al. 2010). All in all, stimulating customer engagement behaviors can build customer relationships, thereby creating value for the initiating company.

Enhanced risk Stimulating customer engagement behaviors can also destroy value when the initiating companies cannot induce customers to comply with company objectives (Hoyer et al. 2010). For instance, the valence of the solicited word-ofmouth can also be negative (e.g., Luo 2009; Verhoef et al. 2013), as the examples of McDonald's and General Motors described earlier show. Moreover, there is evidence that online word-of-mouth has fallen into a negativity spiral, with negative messages appearing in greater volume (Hewett et al. 2016). Thus, there is an increased risk that any negative outcomes of customer engagement will be amplified in the digital environment. Hence, stimulating customer engagement behaviors increases risk for companies, which may negatively affect financial measures (Srivastava et al. 1998).

All in all, we anticipate that firm-initiated customer engagement behaviors can increase the efficiency and effectiveness of value creation and enhance customer relationships, but also increase risk. Investors - who represent the focal stakeholders in our study - may positively evaluate the potential of enhanced and accelerated cash flow resulting from the building of market-based assets; conversely, they may negatively evaluate the ambiguity and increased volatility (Srivastava et al. 1998). We thus pose competing hypotheses and investigate the main shareholder evaluation of a company's customer engagement initiatives empirically.

H1a: Shareholders' evaluations of companies' customer engagement behavior initiatives are positive on average.

H1b: Shareholders' evaluations of companies' customer engagement behavior initiatives are negative on average.

We expect substantial heterogeneity in shareholders' evaluations of firm-initiated customer engagement, partially due to the inherent trade-off between the potential benefits of customer engagement behaviors - efficiency and effectiveness in value creation and building relationships - and the risks associated with them. Whether this trade-off turns out positive or negative is likely to depend on other factors that may amplify or reduce the potential benefits and risks. This is in line with marketing strategy literature documenting that the performance implications of new marketing activities typically depend on strategy characteristics, firm characteristics, and the marketplace (e.g., Geyskens et al. 2002; Homburg et al. 2014).

We focus on the factors that affect the three mechanisms through which customer engagement initiatives may create or destroy value. We expect the efficiency and effectiveness of value creation to heavily depend on the type of customer engagement that is initiated by the company, as well as on 
the supporting channel; furthermore, it will be influenced by how competitive a market is. The extent to which a firminitiated customer engagement initiative is perceived as a beneficial investment in strengthening customer relationships likely depends on what relational investments have already been made, which we capture with customer satisfaction and advertising intensity. Lastly, the shareholders' risk assessment of companies' customer engagement initiatives is likely to depend on corporate reputation, while market turbulence may also increase the risk of customer engagement behaviors (see our conceptual framework in Fig. 1). We acknowledge that these factors can be linked to more than one of the three mechanisms through which customer engagement initiatives may create or destroy value, and we explicitly account for this in the deduction of our hypotheses.

\section{Efficiency and effectiveness of value creation}

Type of customer engagement initiative We distinguish between customer-to-customer interactions (word-of-mouth), such as a company stimulating their customers to write a review or recommend the firm, and customer feedback (voice), e.g., a company inviting their customers to give feedback on for instance a new product or service (Bijmolt et al. 2010; Verhoef et al. 2010), as two general manifestations of customer engagement behavior. Bijmolt et al. (2010) add customer co-creation - for instance, in new product development - as a third manifestation of customer engagement behavior. Contrary to voice and word-of-mouth, co-creation behaviors have a more long-term focus, and are primarily aimed at (internal) product development and value creation (e.g., Hoyer et al. 2010). Given that this manifestation of customer engagement conceptually differs from the other two, we will focus on word-of-mouth and voice initiatives and consider cocreation as a manifestation of customer engagement in an additional analysis.
We expect word-of-mouth initiatives to be more powerful than voice initiatives in increasing the efficiency and effectiveness of value creation. Voice initiatives are directed to the company internally, and do not make use of the potential benefits of customer-to-customer interactions on social networks. With their focus on detecting potential issues in the product and service delivery (Hirschman 1970), voice initiatives may be able to save costs and prevent customer defection, but they do not acquire new customers. Through word-of-mouth initiatives, though, companies are able to acquire new customers, which would imply not only lower costs, but also additional revenues. Previous literature clearly shows that word-ofmouth, especially if it uses electronic platforms, is a powerful tool to attract customers and increase sales. In particular, it outperforms traditional tools such as advertising, because of the high potential reach of (electronic) word-of-mouth, and also because customers trust the recommendations of other customers more than traditional company communication (Babić Rosario et al. 2016; Trusov et al. 2009; You et al. 2015).

Yet the potentially higher returns of word-of-mouth over voice initiatives come at the price of a risk of the initiative backfiring and generating negative word-of-mouth, as we saw earlier with the McDonald's Twitter campaign (Verhoef et al. 2013). Although negative word-of-mouth may according to Babić Rosario et al. (2016) not be detrimental for all product categories, it contributes to a more polarized sentiment that jeopardizes sales. For voice initiatives that are directed to companies internally, the risk of negative outcomes is somewhat lower because a firm can simply decide to not make use of their customers' input. However, customers may negatively react to the firm's lack of responsiveness, and if customers voice their feedback through a non-private communication channel, such as Facebook or Twitter, the feedback may be as visible and impactful as negative word-of-mouth (Claus et al. 2012; Jaakkola and Alexander 2014; Ramani and Kumar 2008).

Fig. 1 Conceptual model

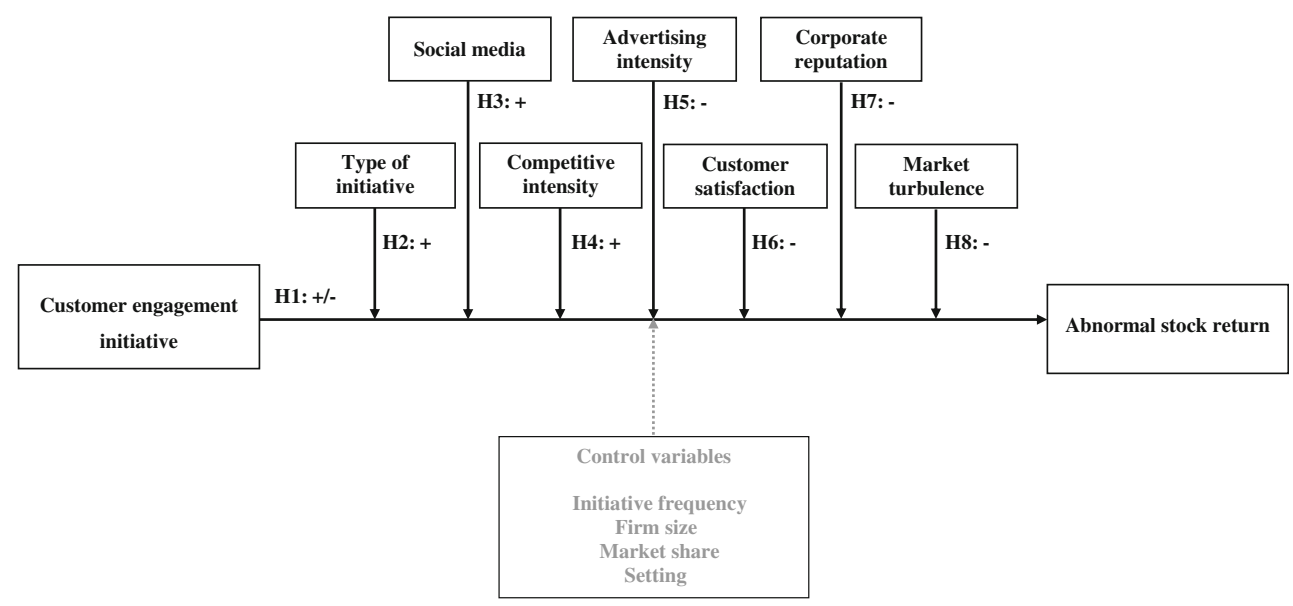


Word-of-mouth initiatives are thus able to generate additional revenue streams while voice initiatives are not. Both types of initiatives have a certain risk of backfiring. Therefore, we expect word-of-mouth initiatives to create more value than voice initiatives.

$\mathrm{H} 2$ : Returns on stimulating customer engagement behaviors are higher for initiatives that stimulate customer word-ofmouth compared to customer voice.

Social media Customer engagement behavior initiatives are more likely to create value when they are supported by a social media channel, such as Facebook, YouTube, or Twitter. First, through social media it is possible to reach a larger audience in a shorter time period (e.g., Libai et al. 2010; Liu-Thompkins and Rogerson 2012), making a customer engagement initiative more effective. For instance, word-of-mouth campaigns are likely to benefit from increased customer reach and faster delivery (Trusov et al. 2009). Nonetheless, negative customer engagement might also spread more quickly through social media channels. Second, a social media channel is a relatively low-cost channel for supporting a customer engagement behavior initiative (e.g., Bayus 2013; Godes et al. 2005), hence initiatives utilizing social media can therefore be more efficient (Trusov et al. 2009). Third, social media can improve the quality of customer-firm interactions (e.g., the sensory content of interactions can be enhanced compared to, for instance, traditional print media, by including video and sound) (Libai et al. 2010), which may yield a more favorable customer experience. Recent studies indicate that social media can indeed create a favorable experience, thereby fostering customer retention (e.g., Malthouse et al. 2013), influencing brand evaluations (e.g., De Vries et al. 2012), and leading to increased sales (e.g., Kumar et al. 2013), amongst other things. We therefore hypothesize:

H3: Returns on stimulating customer engagement behaviors are higher for initiatives supported by social media compared to initiatives that are not.

Competitive intensity Competitive intensity refers to the degree to which a firm faces competition in a market (Morgan and Rego 2009). In concentrated markets, a few large firms dominate, implying a low competitive intensity (Fang et al. 2011). In competitive markets, firms need to act in a more customer-oriented manner, and they also need to differentiate themselves more strongly from their competition (Kirca et al. 2005). Aiming to involve customers in value-creating activities can be considered one of the ultimate forms of customer orientation (e.g., Ramani and Kumar 2008). Therefore, the potential effectiveness of stimulating customer engagement behaviors may be higher in competitive environments. Moreover, stimulating customer engagement behavior can also be used to differentiate the firm from their competition, as it may improve customer relationships (Rust et al. 2000). We thus hypothesize:

H4: Returns on stimulating customer engagement behaviors are higher in environments with a high competitive intensity.

\section{Building customer relationships}

Advertising intensity Firms engage in advertising to create higher customer awareness of their company and the products or services they offer, in the hope of thereby influencing consumer behavior (Vakratsas and Ambler 1999). Advertising contributes to building strong customer relationships, and strengthens supportive behaviors, such as word-of-mouth, and customer loyalty (Bhattacharya and Sen 2003; Polo et al. 2011). Therefore, firms that advertise more may have less to gain from initiating customer engagement because their relationships with their customers are already strong. Indeed, Ou et al. (2017) show that relationship perceptions influence customer loyalty to a lesser extent when firms invest more in advertising.

A countervailing effect where high levels of advertising protect the company against the risk of eliciting negative customer engagement behavior is also conceivable. Yet, in the context of a product-harm crisis, Cleeren et al. (2008) show that the effectiveness of advertising in buffering negative events is limited. Therefore, all in all we expect firms that engage in high levels of advertising to benefit less from initiating customer engagement behavior. ${ }^{2}$

H5: Returns on stimulating customer engagement behaviors are lower with higher advertising intensity.

Customer satisfaction Satisfied customers are shown to be loyal, to buy more, to be willing to pay a price premium, and to engage in positive word-of-mouth (e.g., Palmatier et al. 2006), and satisfaction has also been linked to the superior financial performance of a company (e.g., Anderson et al. 2004). Therefore, companies with a highly satisfied customer base have less to gain from initiating customer engagement, as a customer engagement initiative may be of less added value for building and deepening relationships.

\footnotetext{
${ }^{2}$ One could argue that the public is more informed about a company's customer engagement initiative if that company advertises more, which would suggest an opposite effect. This would in particular hold for advertising that promotes and highlights a firm-initiated customer engagement campaign, while we are examining the effect of general advertising.
} 
A countervailing effect is also conceivable. Initiating customer engagement within a more satisfied customer base may be a less risky endeavor, given that satisfied customers are more likely to act supportively towards the company when invited to participate in customer engagement activities (de Matos and Rossi 2008). Consequently, the risk of customer engagement backfiring may be less pronounced.

In our hypothesis we follow our major customer relationship mechanism, given that the direct effect of satisfaction through leaving little room for improvement of customer relationships is likely to dominate over the more indirect risk effect. Thus we state:

H6: Returns on stimulating customer engagement behaviors are lower with higher levels of customer satisfaction.

\section{Enhanced risk}

Corporate reputation Although firms held in high repute may have a higher ability to elicit positive behaviors, such as positive reviews (de Matos and Rossi 2008; Ho-Dac et al. 2013), companies with a good corporate reputation have more to lose when customer engagement backfires. Reputations are usually slowly and carefully built, but they can be easily destroyed, and specifically so in an era where more digital-communication customer engagement can quickly turn to customer enragement (Leeflang et al. 2014). If that occurs, then building up reputation again is costly and very difficult, as can be observed, for example, in the financial sector (e.g., Hewett et al. 2016). Having a strong reputation is a very valuable asset that needs to be safeguarded, as there are strong consequences for future earnings (Edeling and Fischer 2016). Given that customer engagement initiatives can increase the risk of gaining a negative reputation, it carries with it the potential threat of harming a firm's value. In addition, even the very act of asking for customers' input might signal to investors a potential problem, as companies with a good reputation should not need help from their customers (Fombrun and Shanley 1990).

Building on the relationship mechanism, companies with a good reputation have less to gain from stimulating customer engagement behaviors. Both customer engagement behaviors and corporate reputation create value for companies through relational mechanisms (Fombrun and Shanley 1990; Kumar et al. 2010a); however, companies with good reputations already have strong relationships, so they might not be able to make large improvements.

Yet one could also argue that highly reputed companies have less to fear from negative events such as negative customer engagement behavior. Cleeren et al. (2008) show, for example, that strong brands with a strong reputation have a more robust buffer against a product harm crisis (negative event). Thus, taking this into the customer engagement context, where there are negative consequences (i.e., bashing campaigns), strong brands may have a stronger protection as existing customers are less likely to be influenced by the negative press.

Taken together, we expect that the large risks of customer engagement initiatives and the reduced space for improvement for highly reputed companies are not compensated for by the higher propensity to evoke positive behaviors and the potential buffer effect. We hypothesize:

H7: Returns on stimulating customer engagement behaviors are lower the higher the corporate reputation.

Market turbulence Market turbulence arises because customers' needs and wants change rapidly, so their behavior is volatile (Anderson et al. 1997). As a consequence, the risks of customer engagement initiatives are enhanced. Changing customer preferences may require radical shifts to marketing-mix elements, which customers are unlikely to envision (Gatignon and Xuereb 1997). Therefore, in turbulent markets it may be more risky to leave value creation partially to customers. Second, under demand uncertainty, firms find it "hard to specify the tasks that must be performed, in what manner, and at what level" (Anderson and Weitz 1986, p. 10), increasing the difficulty of coordinating customer engagement behaviors. Third, customers' volatile behavior increases the risk of unexpectedly obtaining negative customer engagement behaviors (e.g., negative word-of-mouth).

One could also argue for a positive role of market turbulence, as it creates a greater need to monitor customers to discover their evolving needs and wants (Gatignon and Xuereb 1997), and stimulating customer engagement behaviors may be a valuable tool to achieve this (Kumar et al. 2010a). In turbulent times, customer-firm relationships are also more important (Rapp et al. 2010). Hence, strengthening the bond with customers may be particularly valuable in times of market turbulence. Yet, given the uncertainty of positive outcomes when stimulating customer engagement in turbulent markets, we hypothesize:

H8: Returns on stimulating customer engagement behaviors are lower with higher market turbulence.

\section{Research design}

\section{Event study methodology}

Event studies have become popular in marketing research to investigate the impact of marketing actions on firm performance, i.e., shareholder value (e.g., Karniouchina et al. 
2011). Recent literature demonstrates that shareholders indeed react to new marketing activities, such as announcements of celebrity endorsements and changes in customer satisfaction (Agrawal and Kamakura 1995; Luo et al. 2010; Srinivasan and Hanssens 2009). We apply the event study methodology to investigate the impact of a company announcing a customer engagement initiative (event) on firm performance and compare the stock return of firm $i$ at the event date (time $t$ ) with the expected stock return had the event not taken place (MacKinlay 1997).

The event study methodology and associated stock return metric offer several advantages over alternative approaches in our research setting. First, unlike accounting measures that use temporal aggregation levels (e.g., sales, profit, return on assets) (Geyskens et al. 2002), an event study methodology allows us to investigate and separate the impact on firm performance of a single press release concerning a company's customer engagement initiative. In contrast, for temporal aggregated metrics, attributing effects to a single event is questionable due to various confounding factors (e.g., Elberse 2007). Second, stock prices are a forward-looking performance metric (Gielens et al. 2008), which enables us to cope with differences in impact duration between different customer engagement initiatives. Moreover, the costs of engagement campaigns may already be present in the short term, whereas the potential benefits (e.g., enhanced customer relationships) may take longer to fully materialize. Third, common performance metrics often study a single benefit or cost, such as sales or revenue, whereas using abnormal stock returns allows us to assess the net effect of companies' customer engagement initiatives. Fourth, an event study can circumvent reversed causality issues, because the methodology supports cause-and-effect inferences in a quasi-experimental setting (Srinivasan and Hanssens 2009).

\section{Sample}

We considered a wide variety of search terms, grounded in prior literature (e.g., Godes and Mayzlin 2004; Hirschman 1970; Kumar et al. 2010b), that relate to customer engagement behavior in general or specific types of customer engagement behaviors. The aim was to find articles in which a company announces an initiative to stimulate customer engagement behavior, i.e., non-transactional customer behaviors. To validate the exhaustiveness of our search terms, we contacted renowned academic researchers working in the customer engagement field; six of them provided feedback, which we addressed by adding 12 search terms (see Appendix A). Through an extensive search on the LexisNexis database of journal and newspaper articles, ${ }^{3}$

\footnotetext{
${ }^{3}$ The large majority of articles came from company press releases distributed through newswires (e.g., PR Newswire); other announcements originated from another source (e.g., a newspaper such as The New York Times) in which the utmost majority contains input from a company's PR members (such as spokespersons).
}

we identified 318 articles that announced companies' customer engagement initiatives. The event date 0 of these articles is the date of the earliest/first appearance of the news report on LexisNexis (cf. e.g., Mathur and Mathur 2000). We conducted this search at two points in time (September-December 2010 and December 2015-April 2016 for an update of our dataset).

To isolate stock price reactions to the event, we removed 82 observations for which there were confounds. ${ }^{4}$ For 114 observations there was no stock price data available in the Datastream database. Therefore, our remaining sample consists of 122 articles announcing customer engagement behavior initiatives, which were coded into distinctive types of customer engagement behaviors by one of the authors and independent coders. ${ }^{5}$ Two researchers coded the used rationales and benefits firms wanted to achieve with the initiative (intercoder reliability .71, disagreements were resolved by discussion): efficiency and effectiveness, customer relationships, and risk. Announcements can refer to multiple mechanisms. The vast majority of the announcements referred to customer relationship improvements (83\%), while $36.4 \%$ of the announcements mentioned the effectiveness/efficiency motive. Only $8 \%$ of the announcements mentioned risk. ${ }^{6}$

Out of the 122 announcements, 61 were classified as wordof-mouth initiatives, 27 as voice initiatives and the remaining 34 as co-creation initiatives (cf. Bijmolt et al. 2010; Verhoef et al. 2010). As pointed out above, as co-creation has a more long-term focus and is primarily aimed at (internal) product development and value creation (e.g., Hoyer et al. 2010), we initially exclude customer co-creation initiatives from our sample and add them in at a later stage as a robustness check.

Our sample therefore consists of 88 announcements of customer engagement behavior initiatives from 67 companies in various industries (for products as well as for service firms and

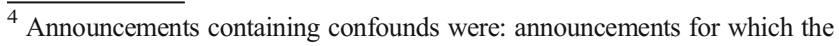
customer engagement behavior initiative was not the primary news (i.e., the announcement also covered more important other news), announcements that were solely backward-looking (i.e., announcements covering the performance of a customer engagement initiative that already took place), announcements by consulting firms that were offering customer engagement solutions, and announcements coinciding with other firm news (specifically, the declaration of dividends, announcement of an impending merger, signing of a major government contract, announcement of a new product, filing of a large damage suit, announcement of unexpected earnings, and change in a key executive; see McWilliams and Siegel 1997).

${ }^{5}$ Two researchers not involved in the project, together with one of the authors, independently coded 107 customer engagement initiatives into distinctive types of customer engagement behaviors. The proportional reduction in loss reliability of the classification among coders was .96 , which implied adequate reliability (Rust and Cooil 1994). Disagreements among coders were resolved by majority vote. One researcher not involved in the project, together with one of the authors, independently coded the 15 customer engagement initiatives collected in the update of our dataset into distinctive types of customer engagement behaviors. The proportional reduction in loss reliability of the classification among coders was .77, which implied adequate reliability (Rust and Cooil 1994). Disagreements among coders were resolved by majority vote or, if there was no majority, discussion and then the author's vote.

${ }^{6}$ We thank the review team for this suggestion.
} 
in a business-to-business [B2B] setting and in a business-toconsumer $[\mathrm{B} 2 \mathrm{C}]$ setting) located in several countries over a 15-year period (1999-2014). These initiatives include the launch of online games (e.g., 3M and JetBlue Airways), the design of user-generated content competitions (e.g., HomeDepot and PetHealth), mobile applications (e.g., AT\&T), and blogs to engage in dialogue with customers (e.g., Lantronix and Samsung). Descriptive statistics of our sample can be found in Table 2, and the initiative headlines can be found in Web Appendix A.

\section{Measures}

Dependent variable Our dependent variable is shareholder value, which we measure with the standardized cumulative abnormal change in stock price over an event window.

Independent variables For denoting the type of customer engagement initiative, a dummy variable takes the value of 1 if an announcement was coded as word-of-mouth (versus 0 for customer voice) based on the coding described earlier. Kaplan and Haenlein (2010, p. 61) define social media as "a group of internet-based applications that build on the ideological and technological foundations of Web 2.0, and that allow the creation and exchange of user generated content" and based on this definition we classified the channel used to support the customer engagement behavior initiative from the announcement; distinguishing customer engagement initiatives that used social media, such as blogs, forums, and user networks, versus those that did not. The Herfindahl Index prior to the announcement year serves as our measure of competitive intensity (e.g., Homburg et al. 2014; Morgan and Rego 2009). Advertising intensity is assessed as the ratio of the firm's investment in advertising to the firm's assets one year prior to the announcement year. Customer satisfaction is captured by the scores in the American Customer Satisfaction Index (www.theacsi.org) one year prior to the announcement year. We used a company's score on Fortune's World's Most Admired Companies list or, if it had no score on that list, on Fortune's America's Most Admired Companies list, as our measure of corporate reputation (Fombrun and Shanley 1990). ${ }^{7}$ We specified market turbulence by regressing industry (four-digit SIC code) sales on year (based on a range of five years

\footnotetext{
${ }^{7}$ Fortune began publicly listing the Most Admired Companies in 2006. Given our time window, we have 14 announcements before 2007. For these announcements we used the score of 2006, as this is our first available measurement. For 35 (out of the total of 88) announcements, the announcing company did not appear on either Fortune's World's Most Admired Companies list or Fortune's America's Most Admired Companies list. We assigned these announcements the lowest score on the Fortune's World's Most Admired Companies list in order to be conservative regarding the lack of reputation for these companies. We also considered using Interbrand brand equity ratings as a measure of reputation. However, there was a substantial number of missing observations; for more than $65 \%$ of the observations, no data were available.
}

Table 2 Sample descriptive statistics

\begin{tabular}{lll}
\hline Variable & & $\begin{array}{l}\text { Number of } \\
\text { initiatives }\end{array}$ \\
\hline Region & North-America & 53 \\
& Europe & 28 \\
& Asia & 7 \\
Year & $1999-2002$ & 4 \\
& $2003-2006$ & 10 \\
Social media & $2007-2010$ & 61 \\
Initiative frequency & $2011-2014$ & 13 \\
& Yes & 69 \\
Type of customer engagement & No & 19 \\
& First announcement & 67 \\
B2B vs. B2C & Subsequent announcement & 21 \\
& B2B firms & 61 \\
Products vs. services & B2C firms & 27 \\
& Product firms & 21 \\
& Service firms & 64 \\
\hline
\end{tabular}

${ }^{a}$ For three announcing companies industry SIC codes were not available, therefore we could not classify this company into product or service firms and $\mathrm{B} 2 \mathrm{~B}$ or $\mathrm{B} 2 \mathrm{C}$ firm

prior to the announcing year), then divided the standard error of the regression slope coefficient by the mean of industry sales (Raassens 2011).

Control variables We controlled for firm size, market share, initiative frequency, and whether the customer engagement initiatives took place in a $B 2 B$ (21 initiatives) versus a $B 2 C$ (64 initiatives) and in a goods (63 initiatives) or services (22 initiatives) setting. Finally, we added dummy variables for each country, announcement year, and season; to avoid overparameterization, we first included all dummy variables, then retained only significant ones in our final analyses (Raassens et al. 2012).

We log-transformed the not normally distributed variables, and replaced missing data points for the independent and control variables with the mean value of the associated variable. An overview of all measures and associated data sources appears in Table 3; the overview of the descriptive statistics and correlations of variables is in Table 4 .

\section{Modeling approach}

Our modeling approach is in line with common practice in event studies (e.g., Boyd et al. 2010; Homburg et al. 2014; Raassens et al. 2014; Sood and Tellis 2009; Borah and Tellis 2014). We estimated normal stock returns using the world 
Table 3 Summary of measures

\begin{tabular}{|c|c|c|}
\hline Construct & Measure & Data source(s) \\
\hline \multicolumn{3}{|l|}{ Dependent variable } \\
\hline Shareholder value & Standardized cumulative abnormal stock return over an event window & Lexis-Nexis, Datastream \\
\hline \multicolumn{3}{|l|}{ Independent variables } \\
\hline $\begin{array}{l}\text { Type of customer } \\
\text { engagement behavior }\end{array}$ & $\begin{array}{l}\text { Dummy coding of customer engagement behavior announcement into customer } \\
\text { word-of-mouth or voice behavior }(1=\text { word-of-mouth). }\end{array}$ & Lexis-Nexis \\
\hline Social media & $\begin{array}{l}\text { Dummy variable indicating whether the customer engagement behavior initiative } \\
\text { is supported by a social media channel }\end{array}$ & Lexis-Nexis \\
\hline Competitive intensity & $\begin{array}{l}\text { The Herfindahl-index (the sum of the squared market shares of all firms within } \\
\text { the same four-digit standard industrial classification (SIC) code); ranging from } \\
0=\text { very high to } 1 \text { = very low competitive intensity. }\end{array}$ & Compustat \\
\hline Market turbulence & $\begin{array}{l}\text { Industry sales are regressed on year (according to five year before the announcement), } \\
\text { and the standard error of the regression slope coefficient is divided by the mean } \\
\text { of industry sales (log-transformed) }\end{array}$ & Compustat \\
\hline Advertising intensity & The ratio of the firm's investment in advertising to the firm's assets (1-year lagged) & Compustat \\
\hline Customer satisfaction & American Customer Satisfaction Index (http://www.theacsi.org/) score (1-year lagged) & ACSI \\
\hline Corporate reputation & Score on the Fortune's World's Most Admired Companies (1-year lagged) & Fortune \\
\hline \multicolumn{3}{|l|}{ Control variables } \\
\hline Firm size & Total amount of company assets (1-year lagged) (log-transformed) & Compustat \\
\hline Market share & A company's sales divided by total industry sales (1-year lagged) & Compustat \\
\hline Initiative frequency & $\begin{array}{l}\text { Dummy variable taking the value of } 1 \text { if a company announced an initiative before, } \\
0 \text { otherwise }\end{array}$ & Lexis-Nexis \\
\hline $\mathrm{B} 2 \mathrm{~B}$ & $\begin{array}{l}\text { Dummy variable distinguishing companies primarily operating in a B2B or B2C } \\
\text { setting, based on the companies' primary four-digit SIC code }\end{array}$ & Compustat \\
\hline Goods & $\begin{array}{l}\text { Dummy variable distinguishing companies primarily operating in a goods or } \\
\text { services setting, based on the companies' primary four-digit SIC code }\end{array}$ & Compustat \\
\hline
\end{tabular}

market model, the most appropriate benchmark for computing normal stock returns in a multicountry event study (Park 2004). That is,

$E\left(R_{i j t}\right)=\alpha_{i}+\beta_{i} R_{m j t}+\gamma_{i} R_{w m t}+\delta_{i} X_{j t}$

where $\alpha_{i}, \beta_{i}, \gamma_{i}$, and $\delta_{i}$ are ordinary least squares parameters; $\mathrm{R}_{\mathrm{ijt}}$ is the day $\mathrm{t}(t=-250, \ldots,-30$, where $t=0$ is the event date) stock return of company $i$ in its home country $j ; R_{\text {mjt }}$ is the return of the market portfolio $m$ in country $j$ on day $t ; R_{w m t}$ is the return of the world market portfolio on day $\mathrm{t}$; and $\mathrm{X}_{\mathrm{jt}}$ is the currency exchange rate in country $\mathrm{j}$ on day $\mathrm{t}$. We used the MSCI World Index as our world market portfolio, together with several local market portfolios (e.g., AEX Index for the Netherlands, Standard \& Poor's 500 Index for the United States) and the currency exchange rate between the U.S. dollar and each local currency, in our estimation.

The difference between $R_{i j t}$ and $E\left(R_{i j t}\right)$ is a measure of the abnormal return $\mathrm{AR}_{\mathrm{ijt}}$ for firm $\mathrm{i}$ from country $\mathrm{j}$ at time $\mathrm{t}$ :

$A R_{i j t}=R_{i j t}-E\left(R_{i j t}\right)=R_{i j t}-\left(\alpha_{i}+\beta_{i} R_{m j t}+\gamma_{i} R_{w m t}+\delta_{i} X_{j t}\right)$

Ideally, the announcement content would not be leaked before the event day, and the dissemination of content occurs fully during the event day (Geyskens et al. 2002). However, these conjectures are often violated (Gielens et al. 2008). To control for potential information leakage (for $t_{1}$ time periods before the event) and information dissemination (for $t_{2}$ time periods after the event), we aggregated the abnormal returns over the event period into a cumulative abnormal return $\left(\mathrm{CAR}_{\mathrm{i}}\right)$ and drew overall inferences for the event of interest:

$C A R_{i}\left[-t_{1}, t_{2}\right]=\sum_{t=-t_{1}}^{t_{2}} A R_{i j t}$

Our event study comprised $88(\mathrm{~N})$ announcements of companies initiating customer engagement behaviors, so we averaged the CAR into a cumulative average abnormal return (CAAR):

$\mathrm{CAAR}\left[-t_{1}, t_{2}\right]=\sum_{i=1}^{N} C A R_{i}\left[-t_{1}, t_{2}\right] / N$.

Next, we assessed the significance of the CAAR using Patell's (1976) statistic (cf. Gielens et al. 2008; Raassens et al. 2014) and standardizing the abnormal returns by the standard deviation of the estimation period's abnormal returns, to account for potential variation in stock return volatility across firms and/or events. The length of the event window $(-\mathrm{t} 1, \mathrm{t} 2)$, reflecting the extent of information leakage and/or dissemination, remained open to empirical verification. Ultimately, we selected the event window on the basis of the significance and parsimony of various estimated CAARs for different event windows (cf. McWilliams and Siegel 
Table 4 Descriptive statistics and correlation matrix

\begin{tabular}{|c|c|c|c|c|c|c|c|c|c|c|c|c|c|c|c|}
\hline & Mean & SD & 1. & 2. & 3. & 4. & 5. & 6. & 7. & 8. & 9. & 10. & 11. & 12. & 13. \\
\hline $\begin{array}{l}\text { 1. Standardized } \mathrm{CAR}_{\mathrm{i}} \\
{[0,+1]}\end{array}$ & -.23 & 1.21 & 1.00 & & & & & & & & & & & & \\
\hline 2. Voice & .31 & n.a. & -.09 & 1.00 & & & & & & & & & & & \\
\hline 3. Social media & .78 & n.a. & .02 & $-.31^{* * * *}$ & 1.00 & & & & & & & & & & \\
\hline 4. Competitive intensity & .27 & .24 & .00 & -.04 & .17 & 1.00 & & & & & & & & & \\
\hline 5. Advertising intensity & .11 & .12 & $-.27^{*}$ & -.24 & .19 & -.08 & 1.00 & & & & & & & & \\
\hline 6. Customer satisfaction & 78.88 & 6.06 & .16 & $-.32^{*}$ & -.16 & -.03 & .14 & 1.00 & & & & & & & \\
\hline 7. Corporate reputation & 5.09 & 1.80 & -.14 & .10 & .07 & -03 & $-.28^{*}$ & -.22 & 1.00 & & & & & & \\
\hline 8. Market turbulence & -4.03 & .73 & -.05 & -.07 & .04 & $.22^{*}$ & -.11 & .26 & $.22^{* *}$ & 1.00 & & & & & \\
\hline 9. Initiative frequency & .24 & n.a. & -.08 & .03 & .16 & -.11 & -.26 & -.21 & $.27^{* * *}$ & $-.16^{*}$ & 1.00 & & & & \\
\hline 10. Firm size & 16.00 & 2.61 & .16 & .15 & -.11 & -.01 & $-.39^{* *}$ & -.10 & $.46^{* * * *}$ & .24 & .15 & 1.00 & & & \\
\hline 11. Market share & .27 & .27 & .11 & -.01 & .12 & $.78^{* * * *}$ & -.05 & -.24 & .13 & .17 & .00 & $.35^{* * * *}$ & 1.00 & & \\
\hline 12. B2B & .25 & n.a. & $.25^{* * *}$ & $.35^{* * * *}$ & -.14 & -.01 & $-.44^{* * * *}$ & $-.47^{* * * *}$ & $.20^{*}$ & -.09 & .05 & .29 & -.08 & 1.00 & \\
\hline 13. Goods & .74 & n.a. & .05 & .03 & -.08 & $.28^{* *}$ & -.14 & .21 & .09 & -.10 & .15 & $.21^{*}$ & $.28^{* * *}$ & $.21^{* *}$ & 1.00 \\
\hline
\end{tabular}

$* p<.10 * * p<.05 * * * p<.01$.

1997). We investigated a 10-day window surrounding the announcement.

We empirically tested our main hypothesis regarding the financial impact of stimulating customer engagement behaviors using the sign and significance of the chosen CAAR. We used a regression analysis of the standardized cumulative abnormal stock returns for individual company announcements (e.g., Agrawal and Kamakura 1995; Geyskens et al. 2002):

$$
\begin{aligned}
C A R_{i}\left[-t_{1}, t_{2}\right]= & \beta_{0}+\beta_{1} \text { type of customer engagement behavior } \\
& +\beta_{2} \text { social media }+\beta_{3} \text { competitive intensity } \\
& +\beta_{4} \text { advertising intensity }+\beta_{5} \text { customer satisfaction } \\
& +\beta_{6} \text { corporate reputation }+\beta_{7} \text { market turbulence } \\
& +\beta_{8} \text { initiative frequency }+\beta_{9} \text { firm size }+\beta_{10} \text { market share } \\
& +\beta_{11} B 2 B+\beta_{12} \text { goods }+\mu_{i},
\end{aligned}
$$

where $\beta_{0}$ is the intercept, $\beta_{1}-\beta_{12}$ are regression parameters belonging to the independent and control variables, and $\mu_{\mathrm{i}}$ is the error term.

There could be some self-selection, as firms may decide to start engagement activities because they could be beneficial for them, which we account for with the Heckman two-step procedure (Heckman 1979), similar to Raassens et al. (2014). In the first step, where we also took into account the clustered nature of the data, we specified a probit selection model to estimate the likelihood that a firm would engage in co-creation versus either word-of-mouth or voice activities, as these types of initiatives differ substantially from each other as argued previously. We used the choice of a specific type of customer engagement behavior instead of a mere announcement of a customer engagement initiative in order to have a sample of non-occurring events (see also Raassens et al. 2014). It would otherwise be highly arbitrary which other events (i.e., which other company announcements) should make up the sample of non-occurring customer engagement behavior announcements.
As explanatory variables in our probit selection model, we used a company's R\&D intensity, a company's SGAE (sales, general, and administrative expenditures) intensity, the growth of the company (as indicated by sales change), the announcement source $(1=$ announcement originated in LexisNexis from a newswire [e.g., PR Newswire], 0 if the announcement originated in LexisNexis from another source [e.g., a newspaper such as The New York Times]), and trend ( $1=$ earliest announcement in sample, 122 = latest announcements). We expect companies that have high R\&D intensity to focus on innovation and to be more likely to stimulate co-creation, whereas companies that have high SGAE intensity should focus on marketing (sales and advertising) and be more likely to stimulate word-of-mouth and customer voice. We do not expect either R\&D intensity or SGAE intensity to affect shareholder value. Indeed, $R \& D$ intensity is a significant predictor of choice of engagement announced $(\beta=4.83, p<.01)$, but not the returns ( $\beta=-.95$, N.S.). For SGAE intensity we did not find significant effects (see Web Appendix B).

As a second step we included the inverse Mills ratio in our regression equation, as described by Heckman (1979). The inverse Mills ratio was not significant in our model. Finally, we assessed the potential threat of multicollinearity. The variance inflation factors (VIF) were all below 5.0, indicating that multicollinearity was unlikely to be a problem.

\section{Results}

\section{Main market valuation of firm-initiated customer engagement behavior (CAAR)}

We examined various event windows to assess empirically the extent of information leakage and/or dissemination. In support 
of H1b, all significant CAARs for different event windows were negative; shareholders, on average, negatively evaluated companies' customer engagement initiatives. The most parsimonious (for means of market efficiency and to limit confounding events) and significant CAAR was CAAR $[0$, $+1]=-.23 \%(p<.05)$. Therefore, we used this event window in our further analyses. The $.23 \%$ decrease in stock returns corresponded to a US\$66.31 million decrease in market value for a median-sized company in our sample.

There is considerable variation in the returns that companies achieve from stimulating customer engagement behaviors. In our sample, $45.5 \%$ (40) of the initiatives exhibited positive abnormal returns over the event period (average $\mathrm{CAR}_{\mathrm{i}}=.75 \%$ ), and the remaining $54.5 \%$ (48) indicated a negative abnormal return (average $\mathrm{CAR}_{\mathrm{i}}=-1.07 \%$ ). We investigated whether announcements referring to different mechanisms are evaluated differently by the stock market using t-tests $(0=$ no, $1=$ presence of mechanism $)$. No significant differences were found for the risk and effectiveness/ efficiency mechanism $(p>.10)$. However, announcements mentioning the relationship mechanism have significant lower abnormal returns $(-.35)$ than announcements not mentioning this mechanism $(.35)(p<.05)$. To test whether the variation in cumulative abnormal returns might be further explained by our moderating variables, we regressed the individual customer engagement behavior initiatives' standardized $\mathrm{CAR}_{\mathrm{i}}[0,+1]$ on our independent and control variables.

\section{Factors affecting the market evaluation of firm-initiated customer engagement behavior}

The results in Table 5 indicate that including additional factors that may amplify or reduce the benefits and risks of stimulating customer engagement behaviors adds explanatory power, over and above a model that includes only control variables $\left(\Delta \mathrm{R}^{2}=.204 ; \Delta \mathrm{F}=3.501\right.$, sig. $\left.<.01\right)$.

In line with $\mathrm{H} 2$, returns are higher for initiatives stimulating word-of-mouth compared to initiatives soliciting customer feedback (voice) $(\beta=.60, p<.05)$. In Fig. 2 , Panel A, we depict the simulated abnormal stock returns for an average customer engagement behavior initiative involving word-ofmouth or voice. ${ }^{8}$ Both, on average, decrease company value; however, the decrease is larger for voice. In support of $\mathrm{H} 3$, we find that returns are higher for initiatives utilizing social media $(\beta=.64, p<.05)$. Figure 2, Panel B reveals that the decrease in company value is larger for a customer engagement initiative without social media utilization. We also predicted that with greater competitive intensity, the returns on the initiatives

\footnotetext{
${ }^{8}$ Figure 2 is based on abnormal stock returns for an average customer engagement behavior initiative. The average is determined by taking the mean value on all variables or the most common value ( 0 or 1$)$ for dummy variables. Low and high levels are determined by taking one standard deviation above or below the mean.
}

for companies would increase (H4). We could find support for this prediction, as the Herfindahl Index as our measure for competitive intensity $(1=$ low, $0=$ high $)$ has a negative effect on stock returns $(\beta=-2.86, p<.01)$. An average initiative for a companies facing high competitive intensity increases firm value; an average customer engagement behavior initiative for a company facing low competitive intensity reduced it (see Fig. 2, Panel C).

We next consider relationship building as our second mechanism through which customer engagement could affect firm performance. As predicted in $\mathrm{H} 5$, although only at the $10 \%$ significance level, returns of companies that advertise more benefit less from initiating customer engagement ( $\beta=-2.94, p<.10)$. When advertising intensity was low, an average customer engagement behavior initiative increased firm value, whereas when advertising intensity was high, such an initiative reduced firm value (see Fig. 2, Panel D). We cannot confirm our prediction that returns on firm-initiated customer engagement behavior are lower for companies with a highly satisfied customer base (H6, $\beta=.05$, n.s.).

With regard to our third mechanism, risk, corporate reputation decreased investors' evaluations of the company's customer engagement behavior initiative, although only at the $10 \%$ significance level $(\mathrm{H} 7, \beta=-.13, p<.10)$. An average initiative for a company with high corporate reputation reduced firm value; an average customer engagement behavior initiative for a company with a low reputation increased it (see Fig. 2, Panel E). Finally, we could not find support for an effect of market turbulence $(\beta=-.11, n . s$.).

In an additional analysis we also included customer cocreation initiatives that we initially excluded from our sample. The direction of the effects remains the same, yet some results become less significant (see Table 5). Furthermore, we find that companies with a higher market share $(\beta=2.24, p<.05)$ and companies acting in a B2B environment $(\beta=1.24$, $p<.01$ ) benefit more from initiating customer engagement behaviors. We carried out several additional analyses to test the robustness of our findings (see Web Appendix C); the results remain stable.

\section{Discussion and conclusion}

Customer engagement has changed customer-firm interactions, prompting companies to undertake proactive efforts to initiate and manage customer engagement behaviors (Beckers et al. 2014). With this study, we investigate the financial consequences of firm-initiated customer engagement, i.e., explicit company strategies to stimulate customer engagement behaviors, and also shed light on the mechanisms that drive this impact.

Our first key finding is that companies' customer engagement initiatives decrease, on average, market value by 
Table 5 Contingencies in the return on firm-initiated customer engagement behavior

\begin{tabular}{|c|c|c|c|}
\hline & Control variables only & $\begin{array}{l}\text { Focal model (voice and } \\
\text { word-of-mouth initiatives) }\end{array}$ & $\begin{array}{l}\text { Voice, WOM and } \\
\text { co-creation initiatives }\end{array}$ \\
\hline \multicolumn{4}{|l|}{ Hypothesized effects } \\
\hline Word-of-mouth (vs. voice) $\left(\mathrm{H}_{2:}+\right)$ & N.A. & $.596(.276)^{* *}$ & $.478(.290)$ \\
\hline Social media $\left(\mathrm{H}_{3:}+\right)$ & N.A. & $.638(.312)^{*}$ & $.467(.261)^{*}$ \\
\hline $\begin{array}{l}\text { Competitive intensity }\left(\mathrm{H}_{4:-}\right) \\
\text { (Herfindahl index: } 0=\text { high, } 1=\text { low) }\end{array}$ & N.A. & $-2.862(1.021)^{* * * *}$ & $-2.444(.985)^{* *}$ \\
\hline Advertising intensity $\left(\mathrm{H}_{5:}-\right)$ & N.A. & $-2.936(1.565)^{*}$ & $-2.306(1.537)$ \\
\hline Customer satisfaction $\left(\mathrm{H}_{6:}{ }^{-}\right)$ & N.A. & $.052(.035)$ & $.052(.033)$ \\
\hline Corporate reputation $\left(\mathrm{H}_{7:}{ }^{-}\right)$ & N.A. & $-.127(.075)^{*}$ & $-.124(.072)^{*}$ \\
\hline Market turbulence $\left(\mathrm{H}_{8:}\right.$ - $^{-}$ & N.A. & $-.112(.182)$ & $-.121(.169)$ \\
\hline \multicolumn{4}{|l|}{ Control variables } \\
\hline Initiative frequency & $-.340(.303)$ & $-.417(.305)$ & $-.065(.257)$ \\
\hline Firm size & $.027(.061)$ & $-.006(.068)$ & $.013(.052)$ \\
\hline Market share & $.178(.564)$ & $2.242(.878)^{* *}$ & $2.025(.873)^{* *}$ \\
\hline B2B (vs. B2C) & $.917(.331)^{* * *}$ & $1.238(.329)^{* * * *}$ & $.608(.268)^{* *}$ \\
\hline Goods (vs. services) & $.014(.310)$ & $.057(.301)$ & $.344(.259)$ \\
\hline Cocreation (vs. word-of-mouth) & N.A. & N.A. & $.161(.287)$ \\
\hline Mills ratio & $.632(.400)$ & $.427(.388)$ & N.A. \\
\hline Intercept & $-1.776(1.125)$ & $-4.775(3.262)$ & $-4.711(3.089)$ \\
\hline Number of observations & 88 & 88 & 122 \\
\hline $\mathrm{R}^{2}$ & .205 & .409 & .260 \\
\hline Adjusted $\mathrm{R}^{2}$ & .113 & .276 & .147 \\
\hline F-value & $2.233^{* *}$ & $3.070^{* * * *}$ & $2.303^{* * *}$ \\
\hline $\begin{array}{l}\Delta \mathrm{F} \text {-value } \\
\text { (relative to control model) }\end{array}$ & N.A. & $3.501^{* * *}$ & $2.771^{* *}$ \\
\hline
\end{tabular}

Parameter estimates (standard errors). Two-sided tests are used for all effects. The dependent variable is the standardized abnormal stock returns CARi[0, +1 ]. Models include significant country and year dummies; we do not report them for simplicity of presentation

$* p<.10 * * p<.05 * * * p<.01$

US\$66.31 million for a median-sized company in our sample. Shareholders are thus likely to respond negatively to customer engagement initiatives, because they are sensitive to the risk of these initiatives backfiring (Hoyer et al. 2010). So far, many studies have highlighted only positive effects of customer engagement (e.g., Kumar and Pansari 2016) and of chatter and word-of-mouth (e.g. Babić Rosario et al. 2016). We clearly show that there might be negative effects of firm-initiated customer engagement initiatives!

We considered not only the main effect for firm-initiated customer engagement, but also when these strategies could be more or less effective. We identified three mechanisms through which this might occur. On the positive side, customer engagement initiatives could (1) make value creation more efficient and/or effective, and (2) improve customer relationships. On the negative side, customer engagement initiatives might (3) be risky for companies and therefore induce negative returns. We find evidence that firms refer to these three mechanisms in their announcements, where increasing customer relationships is the most dominant mentioned mechanism and probably not surprisingly only a few announcements mention risk.

We furthermore find that there is considerable variation in shareholders' responses to various engagement initiatives. Specifically, our results show that initiatives focusing on word-of-mouth are considered to be more effective than initiatives focusing on voice. These results confirm the findings of prior studies that word-of-mouth can indeed be very useful in attracting new customers and creating more sales (e.g. Babić Rosario et al. 2016; Liu 2006). Initiatives using social media are also considered to be more beneficial for firms, as social media are inexpensive and can easily reach huge numbers of customers through network effects (Libai et al. 2010). We also show that customer engagement initiatives are more effective in competitive markets, as they demand more customer-centric activities as well as a stronger differentiation. In sum, our results tend to provide support for the notion that firm-initiated customer engagement can increase the efficiency and effectiveness of value creation under certain boundary conditions. 


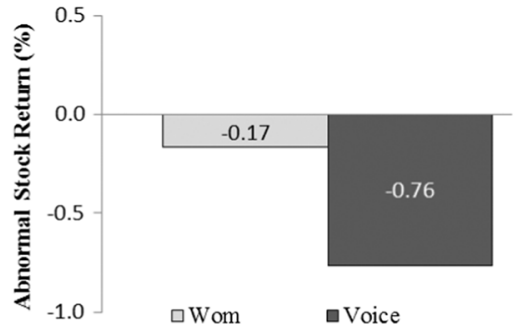

A: Type of $C E$ andreturn on $C E B$

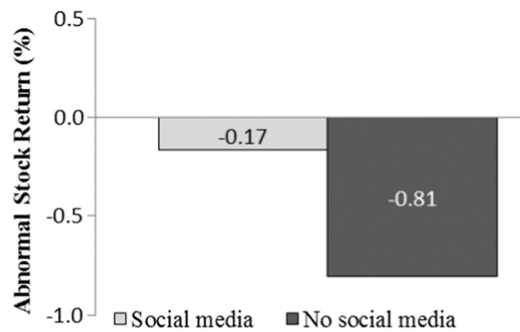

B: Social Media and return on $C E B$

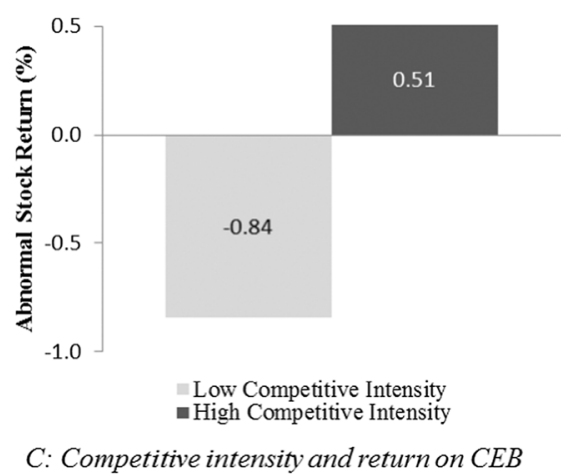

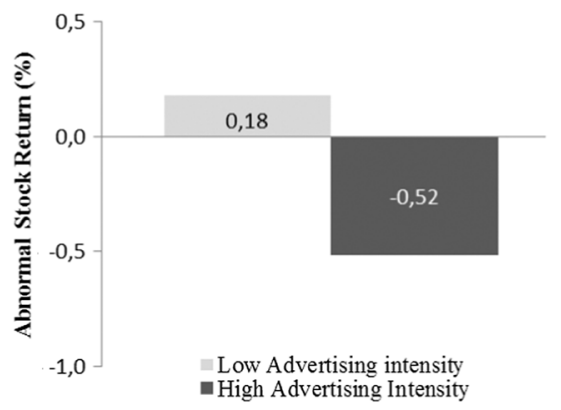

$D$ : Advertising intensity and return on $C E B$

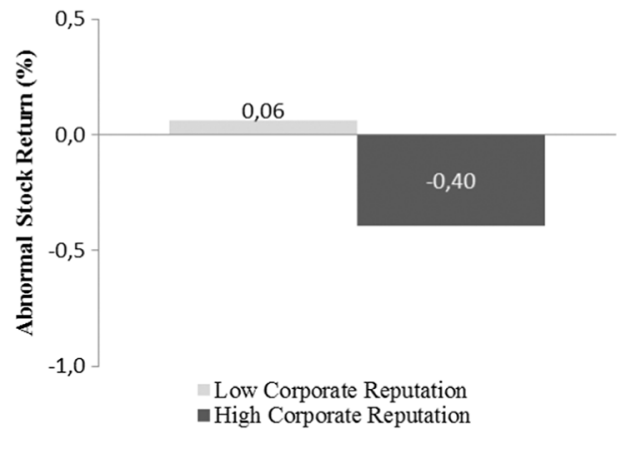

E: Corporate reputation andreturn on $C E B$

Fig. 2 Average returns on firm-initiated customer engagement behavior

We also find some support for the mechanism that customer engagement initiatives can strengthen customer relationships. Specifically, we show that for firms that heavily invest in advertising, initiating customer engagement may not contribute much to further strengthening customer relationships, and therefore is not considered beneficial by shareholders. However, no evidence is found that a similar mechanism occurs for firms with a satisfied customer base. This may be explained by a countervailing effect that customer engagement initiatives might be more effective among satisfied customers who are more likely to respond positively to, for instance, word-of-mouth campaigns. So in sum, our results partially support the presumed customer relationship mechanism underlying the performance consequences of firm-initiated customer engagement initiatives.

Our final suggested mechanism, risk, is also partially supported. Our results provide evidence that firm-initiated customer engagement initiatives are less beneficial for firms with a strong reputation. These firms face a larger risk from potential negative customer engagement manifestations (i.e., bashing). This finding emphasizes that the negative consequences of customer engagement initiatives, as discussed earlier in relation to the experiences of McDonald's and General Motors, can have detrimental effects on firm value. Interestingly, this result counters findings in the existing literature that brands with a strong reputation will be harmed less by negative events (i.e., product recalls) (e.g. Cleeren et al.
2008). Perhaps the social nature of customer engagement and the fear for viral consequences explains this result. No support for a moderating role of market turbulence is found.

We also explored effects of mentioned mechanisms. Interestingly, firms mentioning the relationship mechanism have lower abnormal stock returns. Investors may interpret this as a signal of weakness, as it suggests that firms do not have good customer relationships yet. It may also be that investors believe that firm-initiated customer engagement is not suited to improve customer relationships. Taken together, our findings indicate that investors are predominantly riskaverse with respect to customer engagement initiatives.

We also find some interesting effects of the control variables. Specifically, we find that customer engagement behavior initiatives toward business customers are more positively valued than initiatives by companies that sell to consumers, perhaps due to lower customer heterogeneity and higher customer loyalty levels in most B2B environments (Hoyer et al. 2010).

\section{Managerial implications}

On average, investors expect the downsides (e.g., the threat of negative word-of-mouth) to outweigh the potential benefits (e.g., stronger customer relationships, lower support costs) of customer engagement, resulting in an average decrease of market value of US\$66.31 million for a median-sized 
company in our sample. Therefore, managers need to be cautious when launching initiatives to stimulate customer engagement behaviors. In particular, managers should be aware of the potential dark side of customer engagement, be prepared for their engagement campaign to backfire and have a set of measures ready to manage negative engagement.

Our results also provide clear guidelines in which markets customer engagement initiatives may create positive shareholder responses. In particular, firms in competitive environments and B2B markets could employ customer engagement initiatives to create more value. Therefore, managers of B2C companies should be very cautious in launching customer engagement initiatives, yet at the same time the majority of the announcements that we could identify took place in a B2C environment.

Furthermore, our results suggest that companies that advertise less are more likely to reap benefits from customer engagement initiatives. Managers of those companies can therefore use customer engagement initiatives as a strategy to make up for limited advertising budgets. Yet, on the other hand, firms that already advertise heavily and have a strong reputation should be reluctant to announce customer engagement initiatives.

Lastly, our results also indicate how a customer engagement initiative should be designed to decrease the propensity of negative investor reactions. Given that using social media and focusing on word-of-mouth in engagement is viewed less negatively, managers should focus on word-of-mouth campaigns and have these supported by social media. However, managers should also note that these campaigns are still associated with negative returns, hence a positive reception is not guaranteed.

\section{Limitations and further research opportunities}

Our study has several limitations, which provide potential paths for further research. First, the event study methodology rests on a set of stringent assumptions (Srinivasan and Hanssens 2009) and invariably regards shareholders as the primary relevant group of stakeholders (Geyskens et al. 2002). To assess the effectiveness of a company strategy, additional stakeholders might be taken into account, such as employees and customers. We call for additional research to investigate the impact of firm-initiated customer engagement behaviors on other performance metrics, specifically by considering metrics such as customer satisfaction, sales, and actual shareholder returns for firms implementing these initiatives.

Second, we used publicly available, secondary data to gain access to events in the past and to avoid subjective bias. However, these data do not offer deep insights on the processes (Geyskens et al. 2002). Research using other methods (e.g., qualitative or survey methods) might investigate how customers react to companies' customer engagement behavior programs in different circumstances, for instance also taking more fine-grained differences between different types of social media into account.

Third, customer engagement behaviors resulting from a company's initiatives are likely to have a different impact than customer engagement behaviors that occur naturally (i.e., without the company's interference) (Villanueva et al. 2008). Fourth, for some of our measures our data are incomplete. We assessed the robustness of our results by considering different missing value replacements, yet future research could improve the included measures. Fifth, not all types of shareholders may respond equally to customer engagement initiatives. Future research could disentangle the responses of different types of shareholders (e.g., analysts, individuals, institutions).

Finally, we controlled for selection effects in our study as employed in earlier event studies (e.g., Raassens et al. 2012) that were neither theoretically nor empirically supported. The self-selection correction is not perfect, requiring more attention in future research. Self-selection may for instance not be detected due to the use of weak selection variables (Certo et al. 2016). Moreover, one could argue that firms are selective in which of the implemented customer engagement initiatives they announce. Our method to correct for self-selection does not account for this, also because we do not observe if companies implement a customer engagement initiative without announcing it. Future research could try to alleviate these problems, or take a different perspective and focus on the determinants that drive firms to start with customer engagement initiatives. This could provide more knowledge on which firms would stimulate customer engagement behavior, and why.

Acknowledgements The authors thank the editor, the area editor, three anonymous reviewers, Peter Leeflang, Kenneth Wathne, and Thorsten Wiesel for their useful and valuable comments on a previous draft of this article. They also thank Evert de Haan, Wouter Neef, and Lisan Lesscher for their help coding the data and Kim Lijding and Joris Moossdorff for their help collecting the data.

Open Access This article is distributed under the terms of the Creative Commons Attribution 4.0 International License (http:// creativecommons.org/licenses/by/4.0/), which permits unrestricted use, distribution, and reproduction in any medium, provided you give appropriate credit to the original author(s) and the source, provide a link to the Creative Commons license, and indicate if changes were made.

\section{References}

Agrawal, J., \& Kamakura, W. A. (1995). The economic worth of celebrity endorsers: An event study analysis. Journal of Marketing, 59(3), 56-62.

Alexander, M., \& Jaakkola, E. (2016). Customer engagement behaviours and value co-creation. In R. J. Brodie, L. D. Hollebeek, \& J. Conduit (Eds.), Customer engagement: Contemporary issues and challenges (pp. 3-20). London: Routledge. 
Anderson, E., \& Weitz, B. (1986). Make-or-buy decisions: Vertical integration and market productivity. Sloan Management Review, 27(3), 3-19.

Anderson, E., Day, G. S., \& Rangan, V. K. (1997). Strategic channel design. Sloan Management Review, 38(4), 59-69.

Anderson, E. W., Fornell, C., \& Mazvancheryl, S. K. (2004). Customer satisfaction and shareholder value. Journal of Marketing, 68(4), 172-185.

Babić Rosario, A., Sotgiu, F., De Valck, K., \& Bijmolt, T. H. (2016). The effect of electronic word of mouth on sales: A meta-analytic review of platform, product, and metric factors. Journal of Marketing Research, 53(3), 297-318.

Bayus, B. L. (2013). Crowdsourcing new product ideas over time: An analysis of the Dell IdeaStorm community. Management Science, 59(1), 226-244.

Beckers, S. F. M., Risselada, H., \& Verhoef, P. C. (2014). Customer engagement: A new frontier in customer value management. In Rust, R. T., \& Huang, M. I (Eds.), Handbook of service marketing research (pp. 97-120). Nothamption: Edward Elgar Publishing.

Bhattacharya, C. B., \& Sen, S. (2003). Consumer-company identification: A framework for understanding consumers' relationships with companies. Journal of Marketing, 67(2), 76-88.

Bijmolt, T. H. A., Leeflang, P. S. H., Block, F., Eisenbeiss, M., Hardie, B. G. S., Lemmens, A., \& Staffert, P. (2010). Analytics for customer engagement. Journal of Service Research, 13(3), 341-356.

Borah, A., \& Tellis, G. J. (2014). Make, buy, or ally? Choice of and payoff from announcements of alternate strategies for innovations. Marketing Science, 33(1), 114-133.

Borle, S., Dholakia, U. M., Singh, S. S., \& Westbrook, R. A. (2007). The impact of survey participation on subsequent customer behavior: An empirical investigation. Marketing Science, 26(5), 711-726.

Boyd, D. E., Chandy, R. K., \& Cunha Jr., M. (2010). When do chief marketing officers affect firm value? A customer power explanation. Journal of Marketing Research, 47(6), 1162-1176.

Brodie, R. J., Hollebeek, L. D., Jurić, B., \& Ilić, A. (2011). Customer engagement conceptual domain, fundamental propositions, and implications for research. Journal of Service Research, 14(3), 252271

Brodie, R. J., Ilic, A., Juric, B., \& Hollebeek, L. (2013). Consumer engagement in a virtual brand community: An exploratory analysis. Journal of Business Research, 66(1), 105-114.

Carrabis, J. (2014). The declining value of social marketing. http://www. imediaconnection.com/articles/ported-articles/red-dot-articles/2014/ $\mathrm{jan} /$ the-declining-value-of-social-marketing/. Accessed 16 May 2014.

Certo, S. T., Busenbark, J. R., Woo, H. S., \& Semadeni, M. (2016). Sample selection bias and Heckman models in strategic management research. Strategic Management Journal, 37(13), 2639-2657.

Chan, K. W., Yim, C. K., \& Lam, S. S. K. (2010). Is customer participation in value creation a double-edged sword? Evidence from professional financial services across cultures. Journal of Marketing, 74(3), 48-64.

Claus, B., Geyskens, K., Millet, K., \& Dewitte, S. (2012). The referral backfire effect: The identity-threatening nature of referral failure. International Journal of Research in Marketing, 29(4), 370-379.

Cleeren, K., Dekimpe, M. G., \& Helsen, K. (2008). Weathering productharm crises. Journal of the Academy of Marketing Science, 36(2), 262-270.

De Vries, L., Gensler, S., \& Leeflang, P. S. H. (2012). Popularity of brand posts on brand fan pages: An investigation of the effects of social media marketing. Journal of Interactive Marketing, 26(2), 83-91.

van Doorn, J., Lemon, K. N., Mittal, V., Naß, S., Pick, D., Pirner, P., \& Verhoef, P. C. (2010). Customer engagement behavior: Theoretical foundations and research directions. Journal of Service Research, 13(3), 253-266.
Edeling, A., \& Fischer, M. (2016). Marketing's impact on firm value: Generalizations from a meta-analysis. Journal of Marketing Research, 53(4), 515-534.

Elberse, A. (2007). The power of stars: Do star actors drive the success of movies? Journal of Marketing, 71(4), 102-120.

Fang, E., Palmatier, R. W., \& Grewal, R. (2011). Effects of customer and innovation asset configuration strategies on firm performance. Journal of Marketing Research, 48(3), 587-602.

Fombrun, C., \& Shanley, M. (1990). What's in a name? Reputation building and corporate strategy. Academy of Management Journal, 33(2), 233-258.

Fuchs, C., Prandelli, E., \& Schreier, M. (2010). The psychological effects of empowerment strategies on consumers' product demand. Journal of Marketing, 74(1), 65-79.

Gatignon, H., \& Xuereb, J.-M. (1997). Strategic orientation of the firm and new product performance. Journal of Marketing Research, 34(1), 77-90.

Geyskens, I., Gielens, K., \& Dekimpe, M. G. (2002). The market valuation of internet channel additions. Journal of Marketing, 66(2), 102 119.

Gielens, K., van de Gucht, L. M., Steenkamp, J.-B. E. M., \& Dekimpe, M. G. (2008). Dancing with a giant: The effect of Wal-Mart's entry into the United Kingdom on the performance of European retailers. Journal of Marketing Research, 45(5), 519-534.

Gill, M., Sridhar, S., \& Grewal, R. (2017). Return on engagement Initiatives (RoEI): A Study of a Business-to-Business Mobile App. Journal of Marketing, forthcoming. doi:10.1509/jm.16.0149.

Godes, D., \& Mayzlin, D. (2004). Using online conversations to study word-of-mouth communication. Marketing Science, 23(4), 545560 .

Godes, D., Mayzlin, D., Chen, Y., Das, S., Dellarocas, C., Pfeiffer, B., et al. (2005). The firm's management of social interactions. Marketing Letters, 16(3), 415-428.

Gopinath, S., Thomas, J. S., \& Krishnamurthi, L. (2014). Investigating the relationship between the content of online word of mouth, advertising, and brand performance. Marketing Science, 33(2), 241258.

Gruen, T. W., Osmonbekov, T., \& Czaplewski, A. J. (2006). eWOM: The impact of customer-to-customer online know-how exchange on customer value and loyalty. Journal of Business Research, 59(4), 449456.

Heckman, J. J. (1979). Sample selection bias as a specification error. Econometrica, 47(1), 153-162.

Hewett, K., Rand, W., Rust, R. T., \& van Heerde, H. J. (2016). Brand buzz in the echoverse. Journal of Marketing, 80(3), 1-24.

Hirschman, A. O. (1970). Exit, voice, and loyalty: Responses to decline in firms, organizations, and states. Cambridge: Harvard University Press.

Ho-Dac, N. N., Carson, S. J., \& Moore, W. L. (2013). The effects of positive and negative online customer reviews: Do brand strength and category maturity matter? Journal of Marketing, 77(6), 37-53.

Hollebeek, L. D. (2011). Demystifying customer brand engagement: Exploring the loyalty nexus. Journal of Marketing Management, 27(7-8), 785-807.

Hollebeek, L. D., Glynn, M. S., \& Brodie, R. J. (2014). Consumer brand engagement in social media: Conceptualization, scale development and validation. Journal of Interactive Marketing, 28(2), 149-165.

Hollebeek, L. D., Srivastava, R. K., \& Chen, T. (2016). SD logic-informed customer engagement: Integrative framework, revised fundamental propositions, and application to CRM. Journal of the Academy of Marketing Science, forthcoming. doi:10.1007/s11747016-0494-5.

Homburg, C., Vollmayr, J., \& Hahn, A. (2014). Firm value creation through major channel expansions: Evidence from an event study in the United States, Germany, and China. Journal of Marketing, $78(3), 38-61$. 
Hoyer, W. D., Chandy, R., Dorotic, M., Krafft, M., \& Singh, S. S. (2010). Consumer co-creation in new product development. Journal of Service Research, 13(3), 283-296.

Jaakkola, E., \& Alexander, M. (2014). The role of customer engagement behavior in value co-creation: A service system perspective. Journal of Service Research, 17(3), 247-261.

Kaplan, A. M., \& Haenlein, M. (2010). Users of the world, unite! The challenges and opportunities of social media. Business Horizons, 53(1), 59-68.

Karniouchina, E. V., Uslay, C., \& Erenburg, G. (2011). Do marketing media have life cycles? The case of product placement in movies. Journal of Marketing, 75(3), 27-48.

Kirca, A. H., Jayachandran, S., \& Bearden, W. O. (2005). Market orientation: A meta-analytic review and assessment of its antecedents and impact on performance. Journal of Marketing, 69(2), 24-41.

Kumar, V., \& Pansari, A. (2016). Competitive advantage through engagement. Journal of Marketing Research, 53(4), 497-514.

Kumar, V., \& Reinartz, W. (2016). Creating enduring customer value. Journal of Marketing, 80(6), 36-68.

Kumar, V., \& Shah, D. (2009). Expanding the role of marketing: From customer equity to market capitalization. Journal of Marketing, 73(6), 119-136.

Kumar, V., Aksoy, L., Donkers, B., Venkatesan, R., Wiesel, T., \& Tillmanns, S. (2010a). Undervalued or overvalued customers: Capturing total customer engagement value. Journal of Service Research, 13(3), 297-310.

Kumar, V., Petersen, J. A., \& Leone, R. P. (2010b). Driving profitability by encouraging customer referrals: Who, when, and how. Journal of Marketing, 74(5), 1-17.

Kumar, V., Bhaskaran, V., Mirchandani, R., \& Shah, M. (2013). Creating a measurable social media marketing strategy: Increasing the value and ROI of intangibles and tangibles for hokey pokey. Marketing Science, 32(2), 194-212.

Leeflang, P. S. H. (2011). Paving the way for 'distinguished marketing'. International Journal of Research in Marketing, 28(2), 76-88.

Leeflang, P. S., Verhoef, P. C., Dahlström, P., \& Freundt, T. (2014). Challenges and solutions for marketing in a digital era. European Management Journal, 32(1), 1-12.

Libai, B. (2011). Comment: The perils of focusing on highly engaged customers. Journal of Service Research, 14(3), 275-276.

Libai, B., Bolton, R. N., Bügel, M. S., de Ruyter, K., Götz, O., Risselada, H., \& Stephen, A. T. (2010). Customer to customer interactions: Broadening the scope of word of mouth research. Journal of Service Research, 13(3), 267-282.

Liu, Y. (2006). Word of mouth for movies: Its dynamics and impact on box office revenue. Journal of Marketing, 70(3), 74-89.

Liu-Thompkins, Y. M., \& Rogerson, M. (2012). Rising to stardom: An empirical investigation of the diffusion of user-generated content. Journal of Interactive Marketing, 26(2), 71-82.

Luo, X. (2009). Quantifying the long-term impact of negative word of mouth on cash flows and stock prices. Marketing Science, 28(1), $148-165$.

Luo, X., Homburg, C., \& Wieseke, J. (2010). Customer satisfaction, analyst stock recommendations, and firm value. Journal of Marketing Research, 47(6), 1041-1058.

MacKinlay, A. C. (1997). Event studies in economics and finance. Journal of Economic Literature, 35(1), 13-39.

Malthouse, E. C., Haenlein, M., Skiera, B., Wege, E., \& Zhang, M. (2013). Managing customer relationships in the social media era: Introducing the social CRM house. Journal of Interactive Marketing, 27(4), 270-280.

Mathur, L. K., \& Mathur, I. (2000). An analysis of the wealth effects of green marketing strategies. Journal of Business Research, 50(2), 193-200.

de Matos, C. A., \& Rossi, C. A. V. (2008). Word-of-mouth communications in marketing: A meta-analytic review of the antecedents and moderators. Journal of the Academy of Marketing Science, 36(4), $578-596$.

McWilliams, A., \& Siegel, D. (1997). Event studies in management research: Theoretical and empirical issues. Academy of Management Journal, 40(3), 626-657.

Morgan, N. A., \& Rego, L. L. (2009). Brand portfolio strategy and firm performance. Journal of Marketing, 73(1), 59-74.

Ou, Y. C., Verhoef, P. C., \& Wiesel, T. (2017). The effects of customer equity drivers on loyalty across services industries and firms. Journal of the Academy of Marketing Science, 25(3), 336-353.

Palmatier, R. W., Dant, R. P., Grewal, D., \& Evans, K. R. (2006). Factors influencing the effectiveness of relationship marketing: A metaanalysis. Journal of Marketing, 70(4), 136-153.

Pansari, A., \& Kumar, V. (2017). Customer engagement: The construct, antecedents, and consequences. Journal of the Academy of Marketing Science, 25(3), 294-311.

Park, N. K. (2004). A guide to using event study methods in multicountry settings. Strategic Management Journal, 25(7), 655-668.

Patell, J. M. (1976). Corporate forecasts of earnings per share and stock price behavior: Empirical test. Journal of Accounting Research, 14(2), 246-276.

Polo, Y., Sese, F. J., \& Verhoef, P. C. (2011). The effect of pricing and advertising on customer retention in a liberalizing market. Journal of Interactive Marketing, 25(4), 201-214.

Porter, C. E., Donthu, N., MacElroy, W. H., \& Wydra, D. (2011). How to foster and sustain engagement in virtual communities. California Management Review, 53(4), 80-110.

Raassens, N. (2011). The performance implications of outsourcing. Doctoral dissertation, Tilburg University, Tilburg.

Raassens, N., Wuyts, S., \& Geyskens, I. (2012). The market valuation of outsourcing new product developments. Journal of Marketing Research, 49(5), 682-695.

Raassens, N., Wuyts, S., \& Geyskens, I. (2014). The performance implications of outsourcing customer support to service providers in emerging versus established economies. International Journal of Research in Marketing, 31(3), 280-292.

Ramani, G., \& Kumar, V. (2008). Interaction orientation and firm performance. Journal of Marketing, 72(1), 27-45.

Rapp, A., Trainor, K. J., \& Agnihotri. (2010). Performance implications of customer-linking capabilities: Examining the complementary role of customer orientation and CRM technology. Journal of Business Research, 63(11), 1229-1236.

Rust, R. T., \& Cooil, B. (1994). Reliability measures for qualitative data: Theory and implications. Journal of Marketing Research, 31(1), 114

Rust, R. T., Zeithaml, V. A., \& Lemon, K. N. (2000). Driving customer equity: How customer lifetime value is reshaping corporate strategy. New York: Free Press.

Sood, A., \& Tellis, G. J. (2009). Do innovations really pay off? Total stock market returns to innovation. Marketing Science, 28(3), 442456.

Srinivasan, S., \& Hanssens, D. M. (2009). Marketing and firm value: Metrics, methods, findings, and future directions. Journal of Marketing Research, 46(3), 293-312.

Srinivasan, S., Rutz, O. J., \& Pauwels, K. (2015). Paths to and off purchase: Quantifying the impact of traditional marketing and online consumer activity. Journal of the Academy of Marketing Science, 44(4), 1-14.

Srivastava, R. K., Shervani, T. A., \& Fahey, L. (1998). Market-based assets and shareholder value: A framework for analysis. Journal of Marketing, 62(1), 2-18.

Trusov, M., Bucklin, R. E., \& Pauwels, K. (2009). Effects of word-ofmouth versus traditional marketing: Findings from an internet social networking site. Journal of Marketing, 73(5), 90-102.

Vakratsas, D., \& Ambler, T. (1999). How advertising works: What do we really know? The Journal of Marketing, 63(1), 26-43. 
Vargo, S. L., \& Lusch, R. F. (2004). Evolving to a new dominant logic for marketing. Journal of Marketing, 68(1), 1-17.

Verhoef, P. C., \& Lemon, K. N. (2013). Successful customer value management: Key lessons and emerging trends. European Management Journal, 31(1), 1-15.

Verhoef, P. C., Reinartz, W. J., \& Krafft, M. (2010). Customer engagement as a new perspective in customer management. Journal of Service Research, 13(3), 247-252.

Verhoef, P. C., Beckers, S. F. M., \& van Doorn, J. (2013). Understand the perils of co-creation. Harvard Business Review, 91(9), 28.
Villanueva, J., Yoo, S., \& Hanssens, D. M. (2008). The impact of marketing-induced versus word-of-mouth customer acquisition on customer equity growth. Journal of Marketing Research, 45(1), 4859.

Vivek, S. D., Beatty, S. E., \& Morgan, R. M. (2012). Customer engagement: Exploring customer relationships beyond purchase. Journal of Marketing Theory and Practice, 20(2), 122-146.

You, Y., Vadakkepatt, G. G., \& Joshi, A. M. (2015). A meta-analysis of electronic word-of-mouth elasticity. Journal of Marketing, 79(2), 19-39. 